\title{
Teaching Load as Classroom Based Predictor on Quality Academic Achievement among Girls in Mathematics as a Subject in Secondary Education in Kisumu County
}

\author{
Josephine Adhiambo Agunda, 2018, Henry Onderi, Jack Ajowi
}

Jaramogi Oginga Odinga University of Science and Technology, Kenya.

Abstract: The education of females has a profound effect on national development as lack of their education has been linked to poor sanitation and high illiteracy rate. As the world grows even more dependent on technologically driven competencies, girls' participation in mathematics affects future career and economic opportunities. It is documented that women's participation in mathematics related fields such as engineering is below 20\%. There was therefore need to conduct a study in Kisumu County, Kenya to establish the influence of teaching load as a classroom based predictor as an independent variable on girls' academic achievement in mathematics in secondary education at form four level. The dependent variable was Kenya Certificate of Secondary Education (KCSE) examination results of girls between 2010 and 2014. The objective of the study was to establish the influence of teaching load on girls' academic achievement in mathematics at form four level. Correlation research design was applied to examine the degree of influence that exists between two or more variables by use of statistical data. The target population consisted of 142 public secondary schools which presented female candidates for KCSE between 2010 and 2014, 142 Principals, 142 Heads of mathematics department and 390 mathematics teachers who taught the girls under study. Stratified random sampling technique was applied whereby schools were categorized as girls' secondary schools and mixed secondary schools. Purposive sampling was done to select all the 18 girls' secondary schools in Kisumu County while systematic random sampling was applied to select 38 out of 124 mixed secondary schools in Kisumu County. The sample constituted 39\% of the study population. Data was collected using questionnaires, interviews and document analysis. Instruments of data collection were validated by the researcher's supervisors and reliability of the instruments was established through test retest method by carrying out a pilot study in 5 schools which were not part of the study sample. Quantitative data was analyzed using descriptive statistics in form of frequency counts, percentages, means, Pearson's Product Moment Correlation and regression analysis. Qualitative data from interview schedule was analyzed by using thematic analysis. Statistical Package for Social Sciences (SPSS) version 22 was applied to assist in analyzing data. The findings of the study concluded that there was a negative relationship between teaching load and quality academic achievement among girls in mathematics at form four level. The study recommended that more mathematics teachers should be employed to reduce the teaching load for effective classroom performance.

Keywords: Teaching load, Quality Academic achievement, Classroom based predictor, Secondary school education.

\section{INTRODUCTION}

Mathematics is seen by the society as foundation of scientific and technological knowledge that is vital in socioeconomic development of any nation. There is a general agreement that in any society, every child should study 
Teaching Load as Classroom Based Predictor on Quality Academic Achievement among Girls in Mathematics as a Subject in Secondary Education in Kisumu County

mathematics at school to acquire skills for adult life hence due to this significance, there is greater pressure for girls to succeed in mathematics more than any other subject. Mathematics is compulsory for all students in Kenya due to its major objective of development of thinking ability and logical thought. It aims at developing numerate and rational citizens who are useful in the home, society and nation. It is important in the learning of other subjects and its application in industry and performance in mathematics is of great concern to education stakeholders (KNEC 2015).

A study on children's belief about academic competency found that, beginning at an early age, girls rate their math ability lower than boys do, even when no actual difference in math achievement exists, they therefore lack confidence in math and perform low (Dweck, 2006). Forum for African Women Educationalists (FAWE) studied girls and participation in Science, Mathematics and Technology in Sub-Saharan Africa and established that many girls in Sub-Saharan Africa do not participate significantly or perform well in Mathematics, Science and Technology subjects. It pronounced that situation worsens as the level of education advances and a combination of factors including cultural practices attitudes and biased teaching and learning materials perpetuates the imbalance (FAWE, 2005).

Noraini (2015) in New Zealand postulates that mathematics is a crucial skill in the information age. The achievement in mathematics must be improved to maintain the economic leadership. The writer addressed the point that while technology advances at high speed, poor mathematics performance in schools shortchanges the students' further and endangers the prosperity and nation's security towards technological advancement. Feminist researchers have tried to make meaning of the experiences of girls in the mathematics classroom and to interpret female performance. Their findings revealed that girls are often marginalized and given subordinate status in mathematics class in co-existing high schools.

The need for information technology becomes even more crucial for all developing countries. The roles of girls and women in development are becoming increasing acknowledged and they need to be supported to acquire the necessary skills (FAWE, 2007). FAWE believes that education empowers girls and women to effectively participate in all sectors of national life including the family and community, the economy including agriculture, informal sectors, political participation and decision making and in exercise of their rights under the law. The Forum for African Women Educationists has as its main focus, changing policies aimed at closing the gender gap in education at all levels in Africa. The forum expresses the need to focus on social attitudes towards girls' participation in science and technology, curriculum content and delivery including teacher training and sensitization on gender issues and inclusion of more women teachers in science and technology in order to have more girls enroll and achieve higher levels in mathematics, science and technology.

Education statistics in Sub-Saharan African countries show that women continue to lag behind men in education in general and specifically in science, mathematics and technology. Also, education stereotyping continues with women and girls tending to study programs related to woman's occupation such as nursing, secretarial jobs and social work. (Allison et al, 2008).

In the contemporary Kenya, greater emphasis is being placed on Industrial and Technological development. As a result, students are being encouraged to take up science related subjects and one subject that cut across all the sciences is mathematics (Omondi, 2010). Today, mathematical methods pervade literally every field of human endeavor and play a fundamental role in economic development of a country. In our match towards scientific and technological advancement, we need nothing short of good performance in mathematics at all levels of students in mathematics at the end of secondary education has not improved in the past (Kenya National Examination 
Teaching Load as Classroom Based Predictor on Quality Academic Achievement among Girls in Mathematics as a Subject in Secondary Education in Kisumu County

Council Examination report 2004 - 2011). Various factors have been adduced for poor performance of students in mathematics. The interests of students in mathematics have been related to the volume of work completed, students' task orientation, skill acquisition and students' personality (Wanjohi 2011). Self-concept, feeling of inadequacy, anxiety, shortage of qualified mathematics teachers, poor facilities, use of traditional chalk and talk method and large student to teacher ratio has been studied by FEMSA (2007) as factors influencing achievement in mathematics at high school level across Africa.

This study aims at bridging the gap in the study by answering pertinent questions as to why there is low female representation in courses which require mathematics at higher institutions of learning by addressing the influence of teaching load as a classroom based predictor on academic achievement among girls in the subject.

\section{Statement of the Problem}

The study was necessitated by the deplorable performance of girls at secondary school level particularly in mathematics in Kisumu County. This leads to their under-representation for courses in the field of Science and Technology. In Kenya it has been observed that in spite of the various inputs to education by the government as well as International Organizations, girls still lag behind at all levels of education. Present trends of gender inequality are manifested not only in education but also in the labour market, political leadership and socioeconomic spheres of life. The choice of girls' in this study was influenced by a public outcry in Kisumu County among stakeholders who have called for a probe in to performance of mathematics and science subjects among girls at secondary school level.

The researcher's intention was to examine whether there exists a significant relationship between teaching load and academic achievement among girls at form four level in Kisumu County.

\section{Objective of the Study}

The objective of the study was:

To establish the level of influence of teaching load on girls' academic achievement in mathematics at form four level in public secondary schools.

\section{Hypothesis}

$\mathrm{H}_{01}$ There is no statistical significant relationship between teaching load and quality academic achievement among girls in Mathematics in public secondary schools.

$\mathrm{Ha}_{1}$ There is a statistical significant relationship between teaching load and quality academic achievement among girls in Mathematics in public secondary schools.

The results from regression model was used to test the hypothesis at 0.05 and Ho accepted if the coefficient of the independent variable is statistically not significant and $P$ value is greater than 0.05 . Otherwise Ho is rejected and Ha accepted if the P value is less than 0.05 .

\subsection{Conceptual Framework}

The conceptual framework explains teaching load as the classroom based predictor and it's influence on quality academic achievement among form four female students of 2010 to 2014. However intervening variables expected to alter results were indicated and included students' attitude, school culture, societal beliefs, government policy, peer influence and teachers' attitude as shown in figure 1. 
Teaching Load as Classroom Based Predictor on Quality Academic Achievement among Girls in Mathematics as a Subject in Secondary Education in Kisumu County

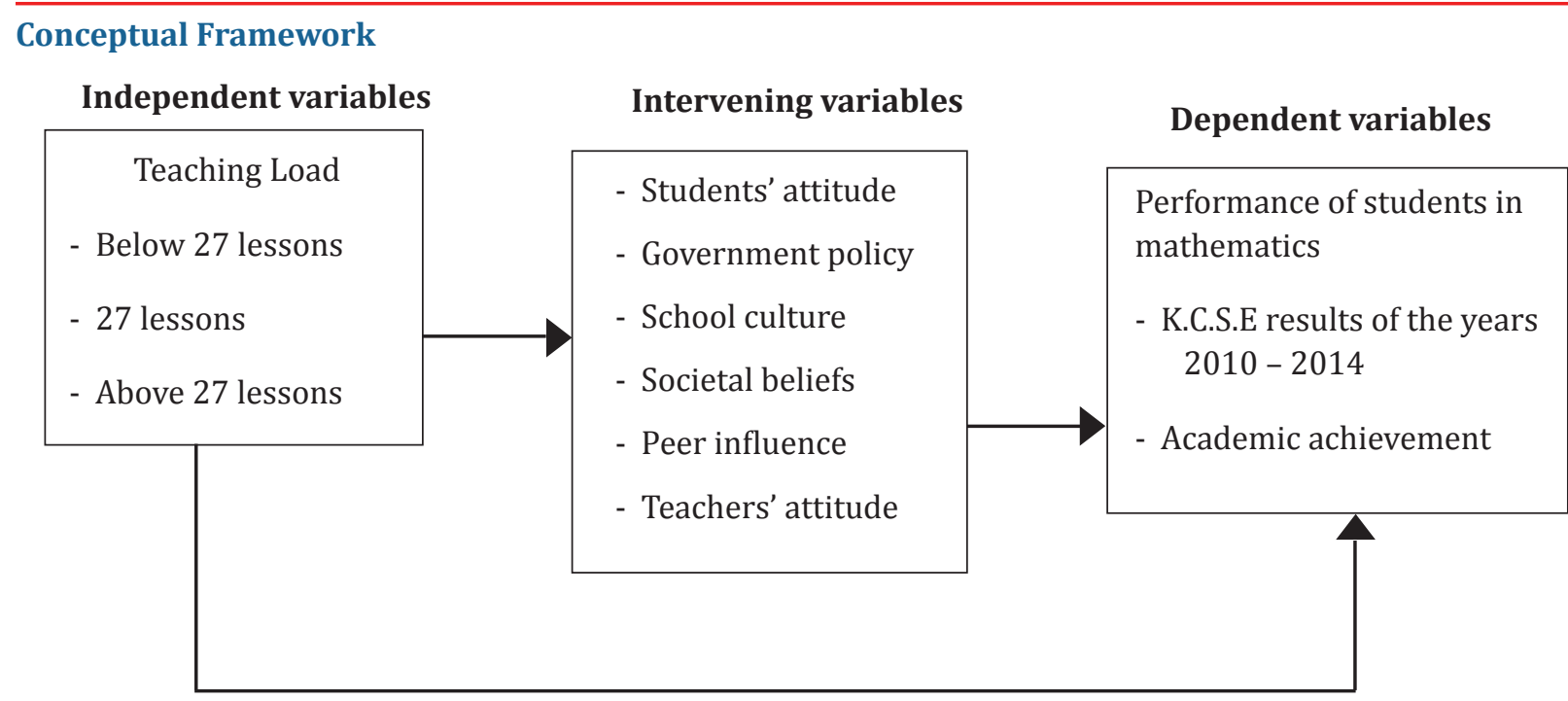

Figure1. Relationship between teaching load and quality academic achievement in mathematics with Intervening variables.

Source: Field data 2017.

Teaching load as the independent variable represents the stimulus while the students' academic achievement in mathematics represent the response. The variable therefore makes clear the kind of statistical treatment that will have to be used to analyze the relationship.

\section{LITERATURE REVIEW}

England has some of the highest-class sizes in the developed world. A report by UNICEF (2007) stated the number of teaching hours per teacher averaged 703 hours in lower secondary education and 782 hours in upper secondary education. Brian (2014), a Professor in mathematics at New Mexico Technical College cited that teaching load of $3+3$ or even $4+4$ is quite common at regional comprehensive universities and Liberal Arts Colleges and was considered high. There has to be a balance between the amount of teaching and research one would like to do, the amount of teaching and research one is expected to do and the amount of teaching and research you are able to do with the teaching load at the institution. Low teaching loads are not a guarantee of happiness (Allison et al (2008)).

A study in Nigeria by Afolabi (2010) examined mathematics teachers' workload visa vis the students' performance in mathematics and revealed that there is a contrast relationship between mathematics teachers' workload and students' performance in mathematics. This might be connected to improper teaching and inadequate coverage of content areas in mathematics that emanated from the additional responsibilities of the teachers. In relation to this, the analysis of 1999 Malawi School Certificate of Education by Malawi National Examination Board revealed that bigger schools had lower percentage passes in Mathematics than the smaller schools. This was explained in terms of teacher's work load. Heavy teaching load leaves little at the disposal of the teacher to help those students in need of assistance (Nherera, 2001).

Studies carried out by Gwambombo (2012) in community secondary schools in Tanzania, Mbeya city, to assess the effect of teachers' workload on students' academic performance revealed that 03 teachers equivalent to $10 \%$ involved in the study said that they were teaching less than 30 periods per week. On the other hand, 2 teachers $(6.7 \%)$ revealed that they were teaching 30 periods per week. Furthermore, 25 teachers (83.3\%) 
Teaching Load as Classroom Based Predictor on Quality Academic Achievement among Girls in Mathematics as a Subject in Secondary Education in Kisumu County

reported that they were teaching more than 30 periods per week. Tanzania's education policy maintains that the maximum number of periods to be taught by a teacher per week is 30 . This implies that most teachers teach more periods than required and affects students' academic performance negatively.

It was revealed that the problem is bigger especially for science teachers due to the fact that only very few females take science. Teachers complained that their teaching load was heavy and that they were not attending all periods allocated in the time table and their teaching was inefficient. For example, one teacher lamented that the teaching load in their school was heavy in all subjects, but the situation was even more discouraging in science because there was no even a single mathematics teacher.

"Teachers have opted to other careers with higher salaries. This situation has added some teaching load to us and has made us not cover all topics. Consequently, our Form II and Form IV students performed very poorly in their final national examinations in 2012"(Mathematics Teacher).

Before the introduction of 8-4-4 system of education in Kenya in 1984, the Kenya Education System was that of 7-4-2-3. In the 8-4-4 system the students undertook 8 years in primary education, 4 years of secondary education, and 4 years of University education. In the 7-4-2-3 system the students went through 7 years of primary education, 4 years of secondary education, 2 years of higher secondary level education and 3 years of university education. In the 7-4-2-3 system of education the staffing norm in secondary schools was determined by one and a half teachers per class. On introduction of 8-4-4 system of education, teacher requirements in secondary schools were determined by Curriculum Based Establishment (CBE) with 27 periods per week lasting 40 minutes each (Ministry of Education 2005). This translated to 18 hours of teaching per week. This is besides time allocated for administrative duties such that the teaching load for head teachers, deputies and heads of departments are lower than 27 lessons (18 hours) per week normally depending on the number of streams in a school.

summarizes the teaching load based on CBE and the number of streams in a school.

Table2. Weekly teaching load based on CBE and number of streams

\begin{tabular}{|l|l|l|l|}
\hline Teacher's Post & $\begin{array}{l}\text { Number of lessons in } \\
\text { single stream }\end{array}$ & $\begin{array}{l}\text { Number of lessons in } \\
\text { Double stream }\end{array}$ & $\begin{array}{l}\text { Number of lessons in Triple } \\
\text { streams and above }\end{array}$ \\
\hline Head teacher & $10-12$ & $8-10$ & $6-8$ \\
\hline Deputy head teacher & $20-24$ & $15-18$ & $12-15$ \\
\hline HOD Job group N & $20-24$ & $15-18$ & $18-20$ \\
\hline HOD Job group M & $20-24$ & $20-24$ & $20-24$ \\
\hline Teacher & 27 & 27 & 27 \\
\hline
\end{tabular}

Source: MOE Circular No. CIS 2/2005.

This report by Ministry of Education (2005) does not concur with the statistic reported by Wamukuru et al (2010) on Demand and Supply of secondary school teachers in Kenya, that teacher in secondary schools in Northern Eastern, Nyanza, Rift Valley and Coast counties are under staffed and that without policy interventions, there will be a teacher shortage of eight teachers at the school level and 79901 teachers' shortage at the National level in the year 2030.

A research done on student's mathematics performance in secondary schools in Nyamira County established that teachers of mathematics had heavy workloads of up to 60 hours per week and revealed to have affected their efficiency (Mochage, 2013). According to the Ministry of Education guidelines on curriculum implementation in Kenya, a teacher in a secondary school is supposed to teach at most 27 lessons in a week. Data obtained 
Teaching Load as Classroom Based Predictor on Quality Academic Achievement among Girls in Mathematics as a Subject in Secondary Education in Kisumu County

showed that $27.8 \%$ of Mathematics teachers teach below 15 lessons per week, $66.7 \%$ teach between $16-30$ lessons, while $27.8 \%$ teach more than 27 lessons in a week. This indicates that $27.8 \%$ of Mathematics teachers are overloaded (Mochagi, 2013).

A study carried out in Kitui Central District in 2009 by Lydia et al on teaching load and girls' performance in science and mathematics at form four level revealed that a greater percentage of the mathematics teachers who taught 27 lessons per week produced a performance range which was above the average performance while the performance range of majority of teachers who taught more than 27 lessons per week was below the average performance. The study further presented findings that a greater percentage of the SMT teachers who taught 27 lessons per week produced a performance range which was above the average performance while the performance range of majority of the SMT teachers who taught more than 27 lessons per week was below the average performance.

Data obtained from studies done by Mbugua et al (2012) in Baringo County in Kenya shows that 8.5\% of mathematics teachers teach below 15 lessons per week, 63.7\% teach between 16 to 30 lessons in a week. This indicates that $27.8 \%$ of mathematics teachers are overloaded and contributed to poor performance in mathematics. Across tabulation between teaching load and students' performance range in Kitui District studied by Lydia, Joash and James (2013) revealed that a greater percentage of Science and Mathematics teachers who taught 27 lessons per week produced a performance range which was above the average performance while performance range of the majority of Science teachers who taught more than 27 lessons per week was below the average performance.

Ajowi et al (2015) in studies carried out in Bondo Sub-County on challenges faced by the school administration while carrying out various welfare practices on secondary school teachers pointed out that principals and teachers confirmed that they are faced with heavy work load since the curriculum is over loaded and that the demand for syllabus coverage, subject and school mean had put unprecedented pressure on Teachers and the Principals. The study further confirmed that very minimal time is left for bench marking in order to discover what is happening elsewhere that need to be borrowed to improve work performance of teaching staff.

The researcher established that there was no study on teaching load that focused on girls' academic achievement in mathematics in public secondary school at Form four level in Kisumu County between 2010 and 2014.

\section{RESEARCH METHODOLOGY}

The chapter provides information on research design, target population, sampling design, data collection instruments, data presentation and analysis of data.

\section{Research Design}

Correlation research design was applied to identify predictive relationships by use of correlations or more sophisticated statistical techniques. This research technique was used to relate two or more variables and allow predictions of outcomes based on causative relationships between the variables (Slavin 2007).

\section{Study Area}

The study was conducted in Kisumu County of Kenya which is one of the newly devolved counties in line with the Kenya Constitution of 2010. Its boundaries follow those of the original Kisumu district one of the former administrative district of the former Nyanza Province in Western Kenya. Its headquarters in Kisumu City.

It boarders Kericho County to the East, Nandi County to the North East, Vihiga County to the North, Siaya County to the West, Homabay County to the South West and Nyamira county to the South. Kisumu County stretches from the Nandi Escarpment in the East to the Kano Plains in the middle all the way to the hills of Nandi West. 
Teaching Load as Classroom Based Predictor on Quality Academic Achievement among Girls in Mathematics as a Subject in Secondary Education in Kisumu County

The Kano Plain is perhaps its most famous feature, sporting black cotton soil that is very fertile. The County has several inselbergs, mostly in the Kisian area. Several rock outcrops also exist, the most famous of them being Kit Mikayi in Seme Sub-County.

Kisumu County has several colleges and universities including Kisumu Polytechnic, Jaramogi Oginga Odinga University Campus, University of Nairobi Campus, Maseno University, Kenyatta University Campus, Great Lakes University, Kisii University Campus, Catholic University of Eastern Africa and Jomo Kenyatta University of Science and Technology. It has a total of 879 schools of which 706 are primary schools and 173 are secondary schools. Of the secondary schools 30 are for boys, 38 are for girls and 105 are mixed secondary schools.

\section{Target Population}

The population of this study consisted of 142 public secondary schools which presented female candidates for KCSE examinations between the years 2010 and 2014, in Kisumu County, 142 Principals of the above schools, 142 Heads of Mathematics Departments and 390 Mathematics teachers who taught the students between 2010 and 2014 within Kisumu County.

\section{Sample Size and Sampling Procedure}

The sample size of 56 (39\%) of the study population which constituted 18 girls' public secondary schools and 38 mixed secondary schools was studied. Stratified sampling technique was used to select 18 girls' Public Secondary Schools and 38 mixed public secondary schools in Kisumu County, 56 Principals of the schools, 56 Heads of Mathematics department and 194 teachers of Mathematics who taught the students between 2010 and 2014. Purposive sampling technique was used to select KCSE results of form four students in mathematics from the girls' public secondary schools, and girls from mixed secondary schools in Kisumu County. It was also applied in selecting five years under study from 2010 to 2014. Systematic random sampling was applied within the stratum for mixed public secondary schools to select the 38 schools.

\section{Research Instruments}

Instruments for data collection comprised of questionnaires for Principals, Heads of Mathematics Departments and Mathematics teachers sampled for the study. Questionnaires obtain facts and opinions about a phenomenon from people and a suitable instrument for data collection because it allows the researcher to reach the respondents and ensures confidentiality of information (Mason 2010). When properly constructed and responsibly administered, questionnaires become a vital instrument by which statement can be made about specific groups or entire population (Mellenberg, 2008). Questionnaires developed by the researcher were used to collect data from principals, heads of mathematics departments and teachers of mathematics in sampled schools. Questions 1, 2 and 3 in all the questionnaires had items based on the background information of the respondents. Each questionnaire had closed ended questions and open-ended questions.

Interviews were conducted to obtain information about the study from Heads of Mathematics Department. Orodho (2012) pinpoints that an interview schedule guides the interviewer to follow up questionnaire responses in depth with smaller samples. An in-depth interview was therefore deemed ideal for investigating where researcher was seeking individual interpretation and responses.

Document Analysis Guide as a tool aided in gathering information from sampled schools on the total number of lessons that the teachers of mathematics had fron 2010 to 2014 in Kisumu County.

\section{ANALYSIS AND RESULTS}

Data summary and classification were done using descriptive statistics and presented using tables, graphs and charts. The collected data was organized and prepared for analysis by coding and entry into Statistical Package for 
Teaching Load as Classroom Based Predictor on Quality Academic Achievement among Girls in Mathematics as a Subject in Secondary Education in Kisumu County

Social Sciences (SPSS)Version 22 software. In order to answer specific research questions, statistical procedures were used including Pearson's Product Moment Correlation Coefficient and Simple regression. The researcher used both quantitative and qualitative data analysis methods to analyze data in an attempt to confirm and validate the findings in the study. The hypothesis was tested at P-value of 0.05 (5\%). Ho (null hypothesis) was rejected as P-value was less than 0.05 and Ha (alternative hypothesis) accepted implying that teaching load as the independent variable is significant in influencing the academic achievement in mathematics. $\mathrm{R}^{2}$ (coefficient of determination) and $r$ (coefficient of correlation) was obtained from the computer printout. Michael (2017) cited the purpose of $\mathrm{R}^{2}$ to establish the proportional change in the dependent variable which is accounted for by the independent variable whereas Bryman and Gramer (2011) explained the application of $r$ to depict the degree of linear relationship. Thematic data analysis was used to analyze qualitative data by recording data in patterns of themes and generating codes (Hay 2009). The verbatim quotes of the interviewees were retained while data were transcribed and initial ideas noted. Different codes were then sorted into various themes as shown in table 1.

Table1. Thematic Data Analysis and Coding of responses from interviews

\begin{tabular}{lcc}
\hline Verbatim Transcripts & Themes/Subthemes & Codes \\
\hline------ -The number of teachers employed & Teaching Load & TL
\end{tabular}

by the Teachers Service Commission are not

adequate to teach mathematics.

---------Teachers have a wide teaching load

Teaching Load

TL

of averagely above 27 lessons per week.

\section{Correlation Analysis}

Teachers were asked to indicate the number of Mathematics lessons they taught per week from 2010 to 2014 and results provided in table 2 .

Table2. Number of Mathematics lessons per week

\begin{tabular}{|l|l|l|l|}
\hline Descriptive Statistics & N & Coded Means & SD \\
\hline lessons per week in 2010 & 180 & 2.13 & .936 \\
\hline lessons per week in 2011 & 180 & 2.04 & .942 \\
\hline lessons per week in 2012 & 180 & 2.10 & .940 \\
\hline lessons per week in 2013 & 180 & 2.19 & .940 \\
\hline lessons per week in 2014 & 180 & 2.18 & .970 \\
\hline Valid N (list wise) & 180 & & \\
\hline
\end{tabular}

Key: 1.0-1.4 = less than 27 lessons, 1.5-2.4=27 lessons, $2.5-3.0=$ more than 27 Lessons, $M=$ mean

$\mathrm{SD}=$ standard deviation

Source: Field data (2017)

Table 2 reveals that on the average teachers in Kisumu county had 27 lessons per week but positively skewed meaning that majority of teachers had more than 27 lessons per week. This is in conformity with the report from the Heads of Mathematics Department interviewed by the researcher which responded that majority of mathematics teachers in the sampled schools had above 27 lessons.

The Population of Mathematics teachers between 2010 and 2014 is shown in table 3. 
Teaching Load as Classroom Based Predictor on Quality Academic Achievement among Girls in Mathematics as a Subject in Secondary Education in Kisumu County

Table3. Population of Mathematics teachers between 2010 and 2014

\begin{tabular}{|l|l|l|l|l|}
\hline Number of mathematics teachers & $\mathbf{x}$ & $\mathbf{f}$ & $\mathbf{x f}$ & Percent \\
\hline $1-2$ & 1.5 & 24 & 36 & 53.4 \\
\hline $3-5$ & 4 & 10 & 40 & 22.2 \\
\hline$>5$ & 5 & 11 & 55 & 24.4 \\
\hline Total & $\mathbf{1 0 . 5}$ & $\mathbf{4 5}$ & $\mathbf{1 3 1}$ & $\mathbf{1 0 0 . 0}$ \\
\hline
\end{tabular}

Source: Field data (2017)

The finding of the study shows that $53.4 \%$ of the Head of Department of Mathematics responded that they had 1-2 Mathematics teachers, 22.2\% of them said they had 3-5 Mathematics teachers and only 24.4 of the HODs of Mathematics stated that they had over 5 Mathematics teachers in their schools. This is confirmed by the calculated mean as:

$\overline{\mathrm{X}}=\frac{\sum \mathrm{xf}}{\Sigma \mathrm{f}}=\frac{131}{45}=2.9$

This implies that on the average, there were three teachers of mathematics in each studied school.

This explains the high teaching load of above 27 lessons per week. The findings of this study concur with the report by Mbugua (2012) that teacher shortage in kenya was in crisis in the year studied. Lydia et al (2013) also ascertained in the research paper on Demand and Supply of secondary school teachers in Kenya that there was acute teacher shortage especially in compulsory subjects at secondary school level. In accordance to the regression finding, the teaching load was negatively and significantly related to performance in mathematics. This contributed to poor performance of girls in mathematics in Kisumu County.

This is illustrated in the chart in figure $\mathbf{1}$.

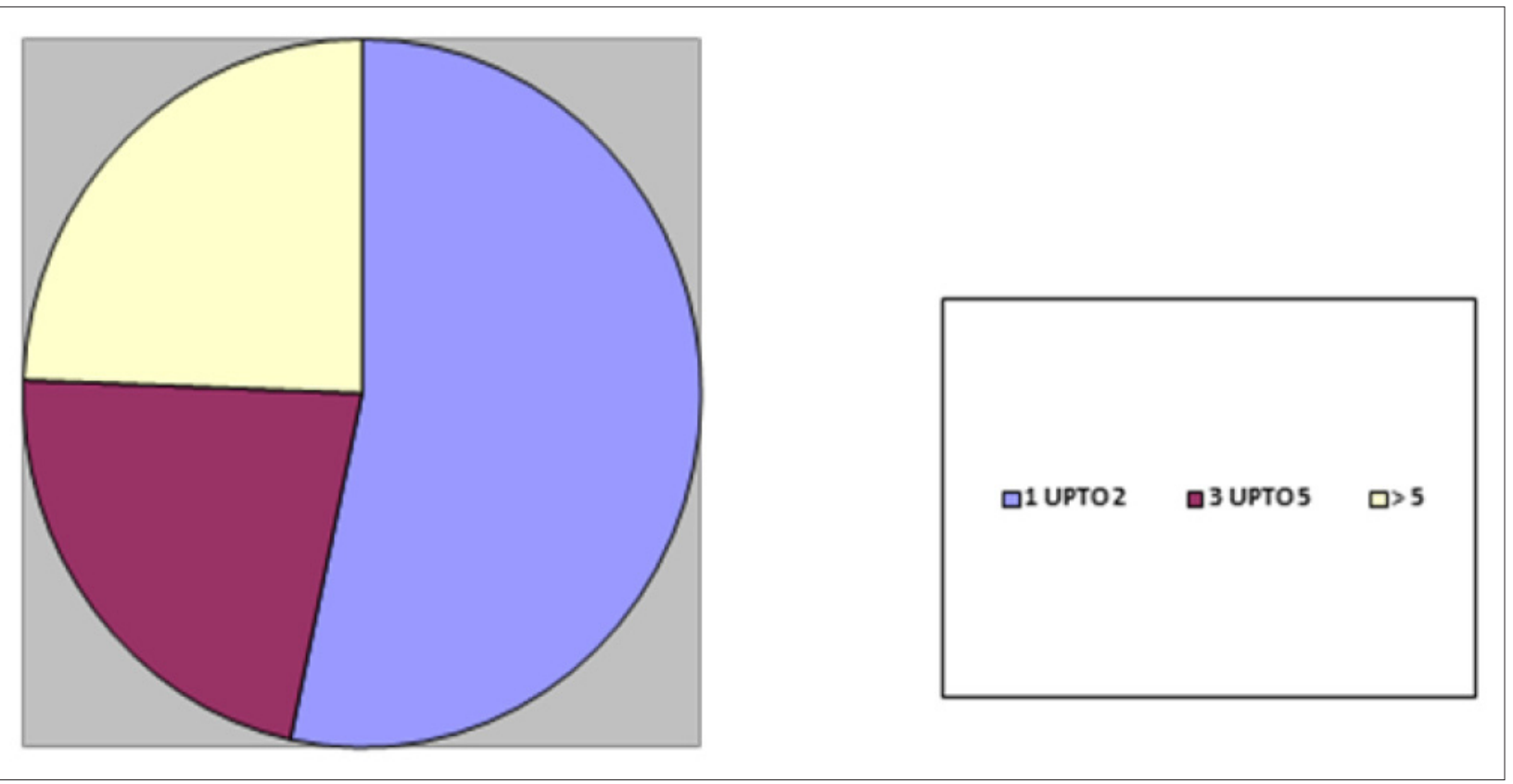

Figure1. Population of mathematics teachers between 2010 and 2014

Source: Field Data (2017) 
Teaching Load as Classroom Based Predictor on Quality Academic Achievement among Girls in Mathematics as a Subject in Secondary Education in Kisumu County

Number of Teachers Teaching Mathematics

Table4. Number of teachers teaching Mathematics

\begin{tabular}{|c|c|c|c|c|}
\hline \multirow[b]{2}{*}{ Number of teachers teaching Mathematics } & \multicolumn{2}{|c|}{ HOD of Mathematics } & \multicolumn{2}{|c|}{ Principal } \\
\hline & $\mathbf{f}$ & $\%$ & f & $\%$ \\
\hline $1-2$ & 24 & 53.4 & 10 & 20.4 \\
\hline 3-5 & 10 & 22.2 & 30 & 61.2 \\
\hline 6-8 & 11 & 24.4 & 6 & 12.2 \\
\hline$>8$ & 0 & 0 & 3 & 6.1 \\
\hline Total & 45 & 100.0 & 49 & 100.0 \\
\hline
\end{tabular}

Source: Field data (2017)

The finding of the study in Table 4 indicates that $53.4 \%$ of the HODs of Mathematics and $20.4 \%$ of the Principals stated that they had 1-2 teachers teaching Mathematics in the school, 22.2\% of the HODs of Mathematics and $61.2 \%$ of the Principals asserted that they had 3-5 teachers handling Mathematics, $24.4 \%$ of the HODs of Mathematics and $12.2 \%$ of the Principals said that they had 6-8 teachers handling Mathematics in the school. Only 6.1\% of the Principals indicated that they had more than 8 teachers handling Mathematics in the schools.

Teachers Adequacy in Handling Mathematics Lessons in the Entire School

Table5. Teachers adequacy in handling Mathematics lessons in the entire school

\begin{tabular}{|l|l|l|}
\hline Response & Frequency & Percent \\
\hline Yes & 21 & 42.9 \\
\hline No & 28 & 57.1 \\
\hline Total & $\mathbf{4 9}$ & $\mathbf{1 0 0 . 0}$ \\
\hline
\end{tabular}

Source: Field data (2017)

The Principals were requested to indicate the number of teachers handling Mathematics lesson in the entire school. The findings in Table 5 shows that $42.9 \%$ of the teachers could handle Mathematics lessons in their school adequately, while $57.1 \%$ of them refuted the statement.

The study result implies that there was inadequate teaching staff of Mathematics in most of the secondary schools in Kisumu County. This explains the high teaching load which has significant negative impact on performance in mathematics. The finding shows that there was need for additional teachers to be employed to teach Mathematics with a view to enhance the performance in the subject.

A correlation between teaching load and academic performance is shown in table 6 . 
Teaching Load as Classroom Based Predictor on Quality Academic Achievement among Girls in Mathematics as a Subject in Secondary Education in Kisumu County

Table6. Correlation of teaching load and quality academic performance in mathematics

\begin{tabular}{|l|l|l|l|}
\hline \multicolumn{2}{|l|}{ Correlations } & Teaching Load & Academic Performance \\
\hline \multirow{4}{*}{ Teaching Load } & Pearson Correlation & 1 & $-.569^{* *}$ \\
\cline { 2 - 4 } & Sig. (2-tailed) & & .000 \\
\cline { 2 - 4 } & $\mathrm{N}$ & 180 & 180 \\
\hline \multirow{4}{*}{ Academic Performance } & Pearson Correlation & $-.569^{* *}$ & 1 \\
\cline { 2 - 4 } & Sig. (2-tailed) & .000 & 180 \\
\cline { 2 - 4 } & $\mathrm{N}$ & 180 & \\
\hline \multirow{2}{*}{$* *$. Correlation is significant at the 0.01 level (2-tailed). }
\end{tabular}

Source: Field Data (2017)

The results of correlation analysis revealed a negative moderate $(r=-.569)$; $p$ value $<0.05)$ relationship between teaching load and quality academic performance, as indicated in the SPSS output in Table 6. Hence from these finding it was reasonable to conclude that there was a negative significant relationship between the teaching load and academic performance.

From this result it implies that if a teacher has a reasonable teaching load it will enhance individual attention to the students and hence will improve academic performance in Mathematics. The same findings are consistent with those from Elizabeth et al (2016) in research findings from studies carried out in secondary schools in Kakamega county, Kenya showed that there was a weak negative relationship between the teaching load a teacher had and Kenya Certificate of Secondary Education performance at r-.214 and $\mathrm{R}^{2}$ at 0.045 meant that a teacher's workload accounted for $4.5 \%$ of the variation in Kenya Certificate of Secondary Education performance. This concurred with these findings that the greater the teaching loads a teacher had, the less likely they were to assist students achieve quality grades at secondary school level.

However, if a teacher has an overload in the number of lessons in the curriculum, it will deny a teacher an opportunity to provide effective individual attention to the students and therefore leading to poor performance in Mathematics. The same findings are consistent with those established from research carried out in Kakamega county, Kenya by Elizabeth et al which established that there was a weak negative relationship between the teaching load a teach had and Kenya Certificate of Secondary Education performance in mathematics. The significance level of 0.000 is less than $P$ value of 0.05 depicting a negative relationship between teaching load and academic achievement in mathematics.

Descriptive statistics revealed that majority of teachers had twenty-seven lessons which according to Teachers Service Commission is the recommended load ( TSC 2013) yet the mean attained by the majority of the girls is below average of $\mathrm{C}+$ in KCSE examination in Kisumu County. There is hence the need to review the teaching load by the Teachers Service Commission to be below 27 to enable a teacher handle mathematic lesson effectively. Further, the regression analysis carried out was to ascertain the significance level between the teaching load and academic performance. The result is summarized in the table 7.

Table7. Model Summary

\begin{tabular}{|l|l|l|l|l|l|}
\hline Model & $\mathrm{R}$ & R Square & Adjusted R Square & Std. Error of the Estimate & Durbin-Watson \\
\hline 1 & $.569^{\mathrm{a}}$ & .324 & .320 & .48903 & .656 \\
\hline \multicolumn{2}{|l}{ a. Predictors: (Constant), Teaching Load } \\
\hline \multicolumn{2}{|l}{ b. Dependent Variable: Academic Performance } \\
\hline
\end{tabular}


Teaching Load as Classroom Based Predictor on Quality Academic Achievement among Girls in Mathematics as a Subject in Secondary Education in Kisumu County

The model summary table 7 reveals that $r$ square is .324 , which indicates that $32.4 \%$ of the academic performance is influenced by the teaching load. The remaining $67.6 \%$ of academic performance is influenced by other factors not in the study.

Table8. ANOVA

\begin{tabular}{|l|l|l|l|l|l|l|}
\hline \multicolumn{2}{|l|}{ Model } & Sum of Squares & Df & Mean Square & F & Sig. \\
\hline \multirow{4}{*}{1} & Regression & 20.414 & 1 & 20.414 & 85.359 & $.000^{\mathrm{b}}$ \\
\cline { 2 - 7 } & Residual & 42.569 & 178 & .239 & & \\
\cline { 2 - 7 } & Total & 62.983 & 179 & & & \\
\hline
\end{tabular}

From the ANOVA table 8, teaching load is significant in the contribution in academic performance since the $\mathrm{p}$ value of 0.000 is less than .05 .

Table9. Coefficients ${ }^{a}$

\begin{tabular}{|l|l|l|l|l|l|l|}
\hline \multicolumn{2}{|l|}{ Model } & \multicolumn{2}{l|l|}{ Unstandardized Coefficients } & Standardized Coefficients & t & Sig. \\
\cline { 3 - 5 } \multicolumn{2}{|l|}{} & B & Std. Error & Beta & & \\
\hline \multirow{2}{*}{1} & (Constant) & 2.350 & .128 & & 18.378 & .000 \\
\cline { 2 - 7 } & Teaching Load & -.532 & .058 & -.569 & -9.239 & .000 \\
\hline \multicolumn{2}{|l|}{ a. Dependent Variable: Academic Performance } \\
\hline
\end{tabular}

Regression model for the relationship between the independent variable and dependent variable is shown in the equation 2 .

In this model: $Y=2.350-.532 x_{1}+e$ equation 2

Where;

$\mathrm{Y}$ is the Academic performance

$\mathrm{x}_{1}$ is Teacher Load

e is the precision error $(0.05)$

\section{DisCUSSION}

A teachers' teaching load in mathematics was arranged as below twenty-seven, twenty-seven and above twentyseven. The study revealed that most teachers had twenty-seven lessons. A higher percentage of $57.1 \%$ refuted that they were capable of handling mathematics lessons in their schools and $42.8 \%$ of principals testified that they hired private teachers to teach mathematics effectively. With majority of teachers having twenty-seven lessons as recommended by the Teachers Service Commission, the mean grade of below $\mathrm{C}+$ in mathematics in Kisumu County instills understanding that the load of twenty-seven lessons is not desirable and does not give a teacher ample time to asses and address individual differences and needs in the subject.

\section{CONCLUSION}

The number of lessons a teacher has influences girls' achievement in mathematics negatively implying that a reasonable teaching load of below 27 lessons enhance individual assessment to students hence improved performance while a large load denies a teacher an opportunity to provide effective attention. 
Teaching Load as Classroom Based Predictor on Quality Academic Achievement among Girls in Mathematics as a Subject in Secondary Education in Kisumu County

\section{Recommendation}

Depending on the ability and understanding of the students in order to attain high scores in mathematics, The Teachers Service Commission should employ more teachers in secondary schools and reconsider the policy of minimum teaching load being 27 since the same teachers are the ones who are charged with the responsibilities as games masters and mistresses, drama and music patrons, guidance and counseling services which also consume a portion of their teaching time. Careers departments in schools should encourage students to choose teaching courses to reduce the shortage in the profession.

\section{Area of Further Research}

Further and related studies are recommended on factors influencing quality academic achievement in mathematics among girls in Private secondary schools in Kisumu County.

\section{REFERENCES}

Afolabi, S. (2010). Teaching Method and Textual Material Variables as correlates of Students' learning outcome in senior secondary school Mathematics. PhD Thesis. Department of Teacher Education University of Ibadan. Ibadan.

Ajowi, J. Otieno, K.and Bosire, J. (2015) challenges faced by the School Administration while carrying out various welfare practices on Secondary School Teachers in Bondo Sub-county, Kenya. Mediterranean Journal of Social Sciences Vol. 6 no. 2 MCSER Publishing, Rome Italy.

Allison, H. and Shirley, H. (2008). Gender Equality in Education in Rwanda: "What is happening to our Girls?" Paper Presented at the South Africa Association of Women Graduates Conference. Capetown May 2007

Bryman,A and Gramer , D (2011). Quantitative Data Analysis with IBM SPSS 17,18,19. A guide for social scientists.London, Routledge

Dweck, C. (2006). Is Math a gift? Stanford University, D.C. American Psychological Association.

Elizabeth, W. Enose, S. and Okwach, T. (2016) Influence of teacher factors on students' academic performance in mathematics in secondary school education. A case study of Kakamega County, Kenya. Research paper. Jer 2016.

Forum for African Women Educationists (2005). The Education of Girls and Women in Africa. Nairobi: Nairobi Publishers.

Forum for African Women Education (2007) Girls' Education: An agenda for change Nairobi:

FEMSA. (2007) Difficulty faced by girls in the study of Science, Mathematics and Technology subjects. Gwombombo, I (2012). The effects of Teachers' workload on students' academic performance in Community Secondary Schools in Mbeya City, Tanzania Unpublished Masters Thesis. University of Tanzania.

Hay, I. (2009). Qualitative Research Methods in Human Geography. (2nd Edition). Oxford: Oxford University Press.

Kenya National Examination Council (2015). The year 2015 KCSE Examination candidate performance report. Nairobi: KNEC centre for curriculum studies in Africa (2015) Basic programme for Post Graduate Diploma in Curriculum Implementation Course Manual. Nairobi Kenyatta University Bureau of Education Research.

Kenya National Examination Councl. K.C.S.E Examination Reports from 2004 - 2011: Nairobi Government Printers. 
Teaching Load as Classroom Based Predictor on Quality Academic Achievement among Girls in Mathematics as a Subject in Secondary Education in Kisumu County

Lydia, M., Joash, M. and James, M. (2013). Determinants of Girls' Performance in Science, Mathematics and Technology Subjects in Public Secondary Schools in Kenya. International Journal of Educational Administration and Policy Studies. Vol. 5 (3) pp 33-42

Mason, M.(2010).'Sample Size and Saturation in PhD Studies using Qualitative Interviews.Qualitative Social Research.London:Sage.

Mellenberg, J. (2008). Research Methods in Education. London: Cromhelm.

Mbugua, Z. (2012) Factors contributing to students' performance in mathematics at Kenya Certificate of Secondary Education. A case of Baringo County, Kenya. Am. J. Contempt. Res 2(6) 87-91.

Michael, J .(2017) Introduction to Quantitative Data Analysis in the Behavioral and Social Sciences.East Carolina University.John Wiley \& Sons Inc.111 River Street, Hoboken,NJ 0703, USA

Ministry of Education Science and Technology (2005). Study of Teacher staffing Norms: Draft Report.Nairobi. TSC.

Mugenda, M. and Mugenda, G. (2013) Research methods. Quantitative and Qualitative approaches, Nairobi, Acts Press.

Mochoge,G. (2013).Determinants of students 'Mathematics performance in secondary schools in Nyamira County, Kenya. Published Thesis.

Nherera, C. (2001). Capacity building in Education Research in South Africa. Empirical insights into qualitative research. Harare. Published by Human Resources Research Centre. University of Zimbabwe.

Noraini,P.(2015) Mathematics in the New Zealand curriculum. American Educational Journal, 3:13-17.

Omondi, O. (2010) Teaching and Learning resources and academic performance in Secondary schools in Bondo District of Kenya. Kampala International University. Uganda: Unpublished PHD Thesis.

Orodho,J.A. (2005 and ) Statistics made user Friendly For Educational social science Research. Nairobi: Masola Publisher.

Teachers Service Commission (2013). Policy on Teaching Load in Secondary Schools in Kenya.

UNICEF (2007). Education for some more than others. A regional study on Education in Central and Eastern Europe and the Commonwealth of Independent States (CEECIS), Geneva: UNICEF CEECIS.

Wamukuru, C. (2010) Performance determinants of K.C.S.E Mathematics in Nyamaiya Division, Kampala International University, Uganada. Unpublished PHD Thesis.

Citation: Josephine Adhiambo Agunda, 2018, Henry Onderi, Jack Ajowi. "Teaching Load as Classroom Based Predictor on Quality Academic Achievement among Girls in Mathematics as a Subject in Secondary Education in Kisumu County". American Research Journal of Humanities and Social Sciences, vol 4, no. 1, 2018, pp. 1-14.

Copyright (c) 2018 Josephine Adhiambo Agunda, Henry Onderi, Jack Ajowi. This is an open access article distributed under the Creative Commons Attribution License, which permits unrestricted use, distribution, and reproduction in any medium, provided the original work is properly cited. 